\title{
ANALISIS PENGEMBANGAN MODEL BISNIS PADA INDUSTRI ANIMASI MENGGUNAKAN BUSINESS MODEL CANVAS YANG TERBATASI BIAYA
}

\author{
Digdoyo Oktapriandi', Muhammad Ridwan Andi Purnomo², Ali Parkhan ${ }^{3}$ \\ Magister Teknik Industri, Fakultas Teknologi Industri, Universitas Islam Indonesia. ${ }^{1,2,3)}$ \\ Jl. Kaliurang km. 14,5, Sleman Yogyakarta, 55584 \\ Email :digdoyo.oktapriandi@gmail.com ${ }^{1)}$,ridwan_ie@uii.ac.id ${ }^{2}$, aliparkhan@uii.ac.id ${ }^{3)}$
}

\begin{abstract}
Business development is an important thing for every company in order to adjust their self to follow the world sophistication. One of business sector is animation that now became more advance along the world development. In Indonesia the business move in the field of animation has not been so ogled by the investors. One big reason is because investors do not know the level of profit to be gained. This study aims to develop a business model company engaged in the field of animation that accompanied the information related to the benefits of investment that will be obtained. the Method used in this research are business model canvas (BMC) and SWOT analysis which being modified with cost analysis. The results obtained is "Kasat Mata" animation company that has been operating for more than 10 years should be develop its business model in order to provide a good profit for the company. Based on cost analysis with several investment feasibility parameters, the business development model is eligible. At the end, this research can be used as a reference for the company for developing their business model and also can be used by investors as a consideration for understanding the benefits.
\end{abstract}

Keywords : Business Development, Animation, Business Model Canvas (BMC), SWOT Analysis, Cost Analysis.

\section{PENDAHULUAN}

Menurut Geertz (1994), di Indonesia terdapat 300 suku bangsa dan menggunakan kurang lebih 250 bahasa daerah. Latar belakang tersebut menyebabkan banyaknya karya yang lahir dari cerita rakyat, legenda maupun kebudayaan yang ada di Indonesia. Salah satu karya yang erat kaitannya dengan kebudayaan adalah karya berbentuk animasi dimana dalam beberapa dekade terakhir teknologi ini sering digunakan untuk mengabadikan sebuah cerita dalam bentuk film animasi.

Kasat mata merupakan salah satu studio animasi senior di Indonesia yang pertumbuhan bisnisnya kurang begitu baik. Menurut penuturan Gangsar Waskito yang merupakan pemilik studio ini berkata bahwa studio miliknya memiliki beberapa permasalahan yang akhirnya berimbas ke grafik pertumbuhan bisnis yang stagnan, jika dilihat dari kacamata finansial perusahaan ini hanya bisa dikatakan survive dan tidak bisa berkembang karena manajemen yang kurang baik dan minimnya laba yang diperoleh walaupun proyek animasi yang didapatkan tidak pernah sepi. Pada akhir tahun 2016 lalu studio kasat mata mulai memperbaiki bisnis modelnya dimana studio ini akan memasuki beberapa pasar produk animasi potensial yaitu pembuatan Intellectual Property (IP), merchandise, sekolah animasi dan yang pasti tetap memproduksi film animasi yang berfokus pada pembuatan karakter animasi.

Model bisnis adalah metode yang digunakan perusahaan untuk menjalankan bisnisnya, yang membuat perusahaan dapat bertahan (Tim PPM Manajemen, 2012). Terdapat beberapa tools yang dapat digunakan dalam memetakan dan mengevaluasi model bisnis perusahaan, salah satunya adalah dengan menggunakan business model canvas. Business model canvas merupakan sebuah bahasa bersama untuk menggambarkan, visualisasi, menilai, dan mengubah model bisnis (Osterwalder, A \& Pigneur, Y, 2010). Pada penelitian ini 
akan diteliti mengenai pengembangan suatu bisnis model pada industri animasi menggunakan metode Bussines Model Canvas (BMC). Setelah mengetahui kerangka BMC perusahaan yang terbentuk, masing-masing elemen dianalisis menggunakan analisis SWOT pada tiap elemen business model canvas. Analisis SWOT merupakan sebuah metode yang membandingkan antara kekuatan, kelemahan, peluang, dan ancaman yang dapat membantu untuk memformulasikan strategi (Fathurahman, A, 2016). Kemudian hasil analisis SWOT digunakan sebagai input untuk merancang model bisnis perbaikan dan prototype business model canvas masa depan. Selanjutnya dengan mempertimbangkan business model canvas yang terbentuk dilakukan studi pengembangan untuk memprediksi seberapa menguntungkan bisnis ini untuk dijalankan. Studi lanjutan tersebut adalah analisis finansial dimana data yang digunakan adalah data Rencana Anggaran Biaya (RAB) untuk menjalankan rencana pengembangan model bisnis yang sudah dianalisis terlebih dahulu menggunakan business model canvas dan analisis SWOT.

Beberapa kajian dalam penelitian yang pernah dilakukan sebelumnya mengenai analisis model bisnis baik dengan menggunakan Bussines Model Canvas (BMC) maupun analisis biaya menunjukan hasil yang positif yaitu dapat mengetahui sejauh apa pengembangan bisnis dapat dilakukan dengan sumber daya yang ada serta memberikan nilai tambah yang menguntungkan bagi perusahaan. Penelitian yang dilakukan Yusuf Mauluddin (2016) mengenai pengembangan model bisnis pada usaha outbond di villa buleud memiliki tujuan untuk mengidentifikasi, mengevaluasi, dan membuat alternatif bagi perusahaan untuk mengambil keputusan berdasarkan Bussines Model Canvas (BMC). Adapun hasil dari penelitian ini berupa data hasil identifikasi model bisnis yang di terjemahkan menggunakan metode bussines model canvas.
Selanjutnya Chandra pada tahun 2016 dalam penelitiannya melakukan analisis terhadap perusahaan $\mathrm{X}$ dengan menggunakan beberapa metode yaitu business model canvas dan analisis SWOT. Adapun tujuan dari penelitian ini adalah untuk mengetahui model bisnis yang diterapkan oleh perusahaan menggunakan business model canvas dan melakukan analisis serta evaluasi untuk mengetahui kekuatan, kelemahan, peluang, dan ancaman sehingga dapat merancangkan model bisnis masa depan. Hasil penelitian menunjukkan bahwa model bisnis perusahaan memerlukan beberapa faktor tambahan ditiap elemen model bisnis agar dapat berkembang dan membawa perusahaan ke arah masa depan yang lebih baik. Penelitian lain yang sejenis adalah penelitian yang dilakukan di restoran Yung Ho oleh Surjogondokusumo (2016).

Penelitian ini bertujuan untuk mengidentifikasi, menganalisa dan mengembangkan model bisnis pada restoran Yung Ho dengan menggunakan evaluasi Business Model Canvas. Setelah mengidentifikasi Business Model Canvas, maka akan dilakukan analisis pada setiap elemen yang terdiri dari customer segments, value propositions, channels, customer relationship, revenue streams, key resources, key activities, key partnership, dan cost structure, dengan analisis SWOT. Hasil analisa Business Model Canvas, terdapat beberapa elemen dalam model bisnis yang dapat dikembangkan lebih lagi.

Kemudian penelitian yang terkait dengan analisis biaya adalah penelitian yang dilakukan Maskur (2014) yang meneliti mengenai studi kelayakan investasi pada SPBU CV. Insani Subur Sejahtera di kutai kartanegara dengan menggunakan metode penilaian analisis kuantitatif yaitu Payback Period (PP), Net Present Value (NPV), Internal Rate of Return (IRR), dan Profitability Index (PI) untuk mengkaji proyek investasi pada SPBU tersebut dimana hasil penelitiannya adalah jika ditinjau dari aspek keuangan investasi ini sudah memenuhi tingkat kelayakan yang 
diinginkan. Selanjutnya Utomo pada tahun 2014 melakukan analisis kelayakan finansial terhadap pembangunan sarana retest, repair dan repaint tabung gas $\mathrm{LPG} 3 \mathrm{~kg}$ dimana studi kasus dilakukan di PT. MK Tabanan, Bali. Dimana pada penelitian ini menggabungkan penilaian aspek finansial (kuantitatif) dan penilaian pada aspek nonfinansial (kualitatif). Pada aspek finansial menggunakan perhitungan NPV, IRR, PP dan PI. Sedangkan pada aspek non-finansial menggunakan analisis lingkungan industri yaitu dengan pendekatan Porter's 5 Forces.

Dari kelima penelitian yang pernah dilakukan diatas, analisis model bisnis dengan beberapa metode yang telah dijabarkan dirasa telah dapat menjawab permasalahan yang ada. Selanjutnya penilaian kelayakan investasi pada aspek finansial juga telah banyak digunakan diberbagai bidang industri yang berbeda. Merujuk pada penelitian sebelumnya, maka penelitian kali ini menggunakan beberapa metode yang digabungkan sehingga hasil penelitian akan menjadi lebih kaya akan studi ilmiah untuk menjawab pertanyaan seputar model bisnis dan kelayakan investasi. Adapun metode yang digunakan adalah business model canvas yang dipadu dengan analisis SWOT serta dimodifikasi menggunakan perhitungan analisis biaya yaitu Net Present Value (NPV), Benefit / Cost Ratio (BCR), Internal Rate of Return (IRR), Profitability Index (PI), Payback Period (PP) dan Break Even Point (BEP).

Business Model Canvas (BMC) merupakan salah satu alat strategi yang digunakan untuk mendeskripsikan sebuah model bisnis dan menggambarkan dasar pemikiran tentang bagaimana organisasi menciptakan, memberikan, dan menangkap nilai. Business Model Generation lebih populer dengan sebutan Business Model Canvas adalah suatu alat untuk membantu pelaku usaha dalam melihat lebih akurat bentuk usaha yang sedang atau akan dijalaninya. Gambar dibawah ini menunjukan konsep pemetaan elemen bisnis pada business model canvas.

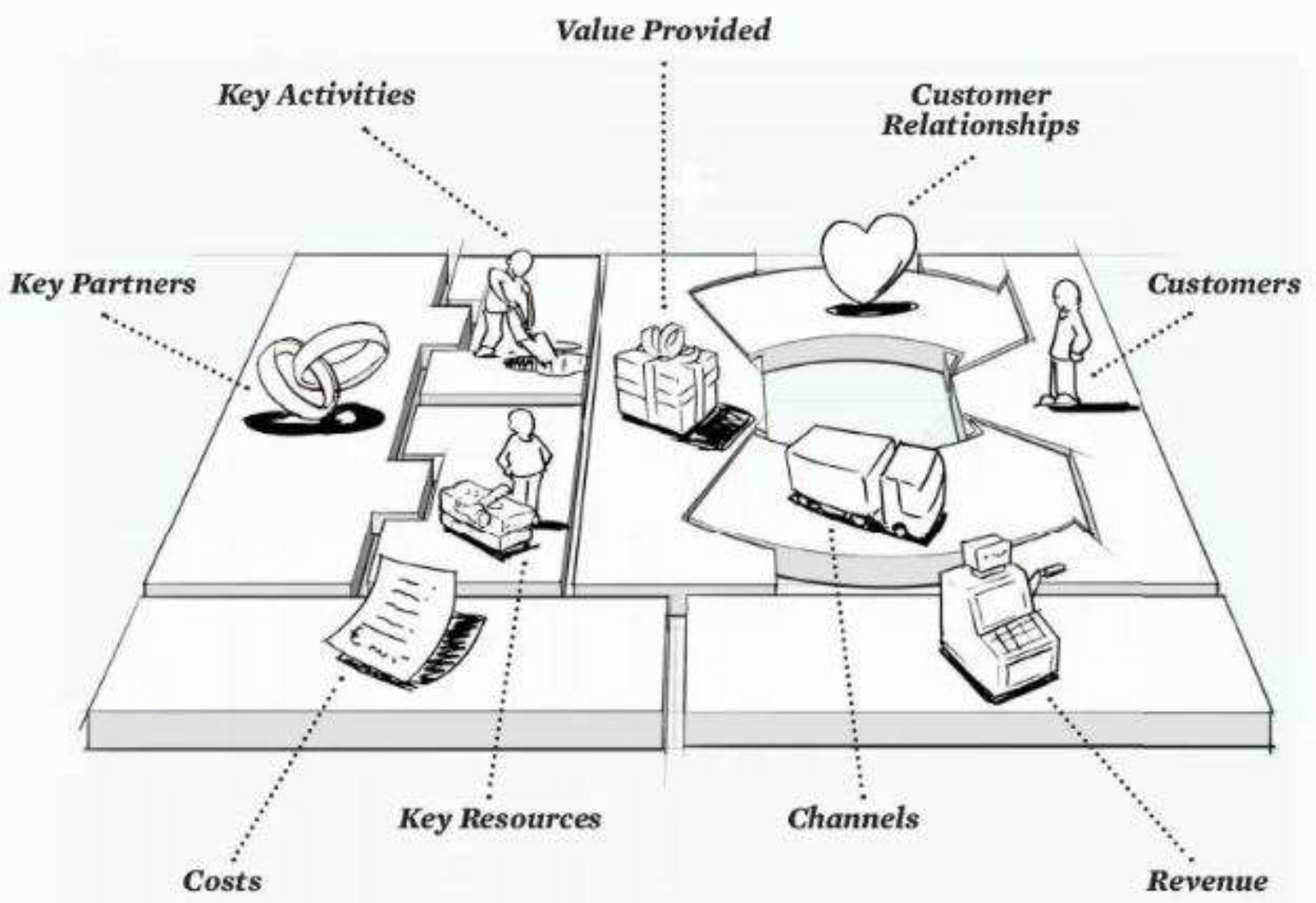

Gambar 1. Sembilan Blok Business Model Canvas.

(Sumber : Osterwalder, A \& Pigneur, 2010) 
Metode BMC mengubah konsep bisnis yang rumit menjadi sederhana yang ditampilkan pada satu lembar kanvas berisi rencana bisnis dengan sembilan elemen kunci yang terintegrasi dengan baik didalamnya mencangkup analisis strategi secara internal maupun ekternal perusahaan (Clark, T, etc., 2012).

Business model canvas juga digunakan sebagai alat untuk memberikan usulan dalam merancang model bisnis. Salah satu cara yang efisien adalah dengan melakukan evaluasi menggunakan metode SWOT (Strength, Weakness, Opportunity, Threat). Ada cara efektif untuk menilai keseluruhan model bisnis yaitu dengan mengombinasikan analisis tentang kekuatan, kelemahan, peluang dan ancaman (SWOT) dengan 9 elemen yang ada dalam Business Model Canvas (Osterwalder, A \& Pigneur, 2010).

Menurut Rangkuti (2016) analisis SWOT adalah identifikasi berbagai faktor secara sistematis untuk merumuskan strategi perusahaan. Analisis ini didasarkan pada logika yang dapat memaksimalkan kekuatan (Strengths) dan peluang (Opportunities), namun secara bersamaan dapat meminimalkan kelemahan (Weaknesses) dan ancaman (Threats). Proses pengambilan keputusan strategis selalu berkaitan dengan pengembangan misi, tujuan, strategis dan kebijakan perusahaan. Dengan demikian perencanaan strategis (strategic planner) harus menganalisis faktor - faktor strategis perusahaan (kekuatan, kelemahan, peluang dan ancaman) dalam kondisi yang ada saat ini.
Berdasarkan hasil pengembangan business model canvas dengan analisis SWOT tersebut dilakukanlah analisis biaya terhadap keseluruhan bisnis model yang terbentuk. Adapun analisis finansial ini dilakukan terhadap rancangan anggaran biaya (RAB) untuk menjalankan rancangan business model canvas yang terbentuk.

Dalam aspek finansial ini akan disajikan informasi tentang biaya investasi, modal kerja, cash flow dan biaya operasional yang terdiri dari fixed cost dan variable cost. Sebelum menyusun analisis kelayakan finansial maka perlu dibuat ihktisar biaya investasi. Cash flow merupakan aliran kas dari suatu usaha yang terdiri dari penerimaan usaha (inflow) dan pengeluaran usaha (outflow). Aliran kas disusun untuk menunjukan perubahan kas selama satu periode tertentu serta memberikan alasan mengenai perubahan kas tersebut dengan menunjukkan dari mana sumber - sumber kas dan penggunaan penggunaannya (Umar, Husein, 2003). Kelayakan investasi dapat diukur dari berbagai kriteria, yang dalam penelitian ini menggunakan analisis break even point (BEP), benefit / cost ratio (BCR), payback periods (PP), net present value (NPV), profitability index (PI), internal rate of return (IRR). Dimana setiap analisis mempunyai kelebihan dan kekurangan masing - masing sehingga penggunaan keenam alat analisis keuangan tersebut akan saling melengkapi dan dapat memberikan hasil yang optimal. 


\section{METODOLOGI PENELITIAN}

Adapun diagram alir penelitian yang tersusun secara terstruktur dari awal hingga berakhirnya penelitian dapat dilihat pada gambar dibawah ini

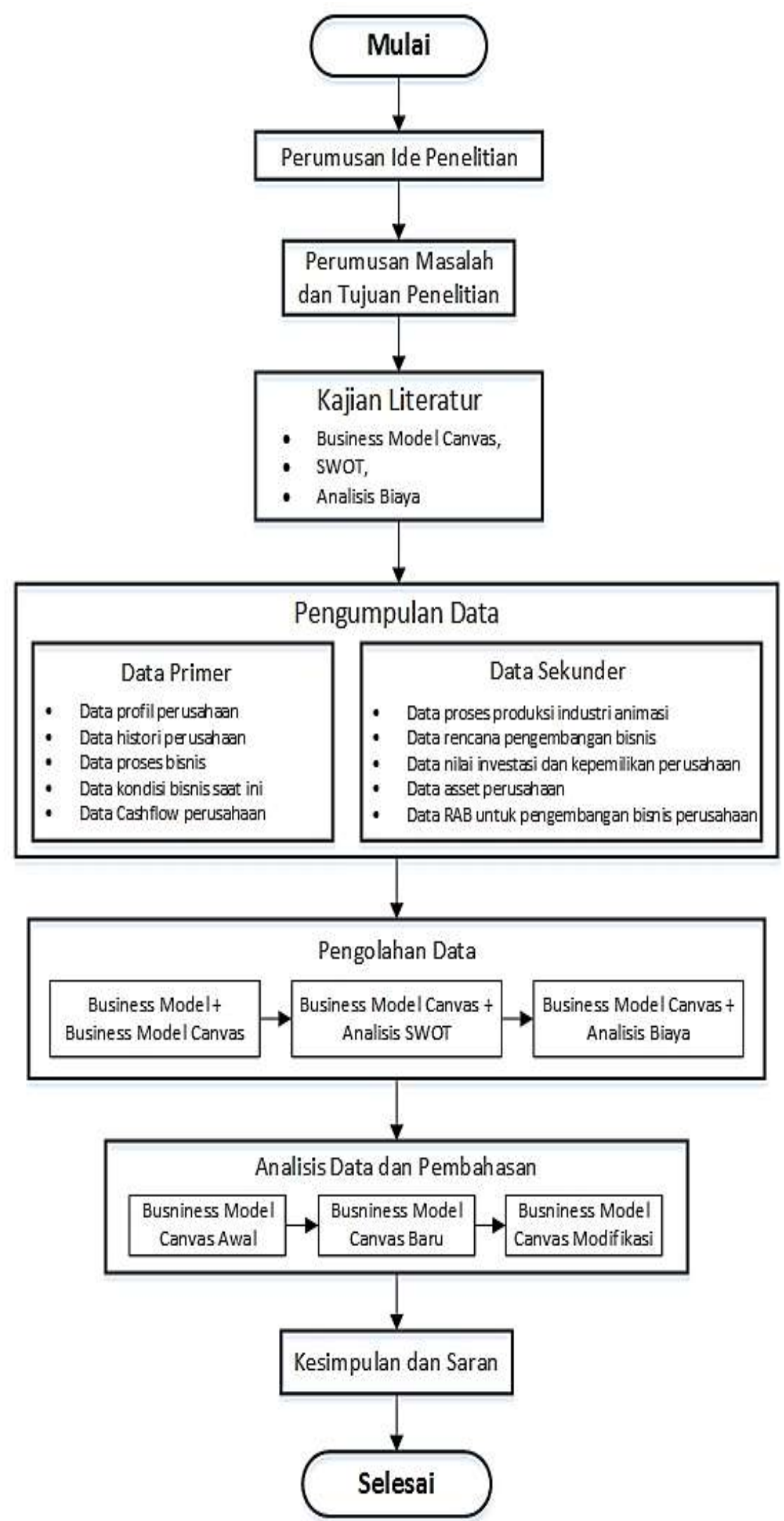

Gambar 2. Diagram Alir Penelitian. 


\section{HASIL PENELITIAN DAN PEMBAHASAN \\ 3.1. Business Model Canvas Awal}

Dalam proses analisis ini dapat diketahui mengenai penjabaran proses bisnis perusahaan animasi kasat mata dalam bentuk Business Model Canvas (BMC). Perusahaan yang sudah berdiri lebih dari 10 tahun ini memiliki proses bisnis yang cukup ramping dimana hanya terdapat 2 lini bisnis yang dijalankan. Dari kedua lini bisnis yang bersifat make to order ini terkadang tidak mampu untuk menerima proyek baru ketika proyek lama belum selesai. Hal ini terjadi dikarenakan kapasitas produksi yang terbatas serta kurang adanya sistem yang memadai baik berupa prosedur maupun infrastruktur. Adapun 2 lini bisnis tersebut adalah proyek film animasi dan pengembangan intellectual property (IP). Pemasukan yang paling besar dari kedua lini bisnis tersebut adalah dari proyek pembuatan animasi. Identifikasi business model canvas awal ini bertujuan untuk mengetahui seluruh seluk beluk proses bisnis beserta elemen pendukungnya yang sesuai dengan konsep business model canvas. Dimana pada konsep ini penjelasannya dibagi menjadi 9 elemen bisnis yang saling berkaitan satu sama lain. Gambar dibawa ini memetakan identifikasi business model canvas awal yang terbentuk.

\subsection{Evaluasi Business Model Canvas Dengan Analisis SWOT}

Pada tahap penelitian ini business model canvas yang terbentuk pada tahapan analisis sebelumnya akan dievaluasi lebih dalam menggunakan analisis SWOT pada kesembilan elemennya. Dimana tujuannya adalah untuk memaksimalkan kekuatan (Strength) dan peluang (Opportunity) serta secara bersamaan dapat meminimalkan kelemahan (Weakness) dan ancaman (Threat). Adapun hasil analisis SWOT yang dilakukan terhadap kesembilan elemen business model canvas adalah sebagai berikut :

\section{- Customer Segments}

Kekuatan dari perusahaan ini adalah terletak pada kerja sama dengan perusahaan animasi lain sehingga proyek - proyek animasi sering datang dari kerja sama ini. Adapun kelemahannya adalah konsumen kasat mata saat ini tidak begitu banyak. Hal tersebut dikarenakan tidak adanya tim khusus untuk menarik konsumen seperti tim marketing dan penjualan. Jika dilihat pada elemen ini perusahaan animasi kasat mata memiliki banyak peluang yang dapat dimanfaatkan seperti sekolah regular yang membutuhkan pelatihan animasi, kerja sama dengan pemerintah dan lembaga pendidikan untuk mengadakan workshop animasi yang menyasar konsumen anak usia dini maupun umum. Selain itu juga melakukan kerja sama dengan perusahaan pembuat merchandise sehingga dengan budaya kolaborasi tersebut dapat menekan biaya produksi dan memaksimalkan penjualan. Ancaman yang terjadi pada elemen ini adalah konsumen yang saat ini lebih memilih bekerja sama dengan perusahaan animasi lain karena lebih canggih dalam hal peralatan dan tim yang lebih solid.

\section{- Value Propositions}

Kekuatan yang dimiliki perusahaan berdasarkan elemen ini adalah selain mengerjakan proyek animasi studio kasat mata sampai saat ini selalu menghasilkan karya - karya animasi yang dapat dinikmati banyak kalangan. Karya tersebut berupa IP yang dipublikasikan melalui sosial media maupun blog dari studio ini sehingga studio kasat mata mempunyai keistimewaan dan kecintaan yang dalam terhadap dunia animasi. Adapun kelemahannya terkadang dalam mengerjakan sebuah proyek terdapat kendala teknis diakibatkan sarana yang kurang memadai sehingga yang seharusnya itu menjadi nilai lebih malah terkesampingkan. Kemudian peluang perusahaan pada elemen ini adalah seharusnya perusahaan ini dapat melayani konsumen lebih baik lagi pada setiap jasa yang ditawarkan jika sarana dan 
prasarananya mendukung. Sedangkan ancaman yang muncul hingga saat ini adalah ancaman internal seperti masalah yang tidak diharapkan tiba tiba muncul ketika proses pengerjaan jasa animasi dilakukan, hal ini bisa terjadi karena keterbatasan manusia dan alat yang dimiliki.

\section{- Channels}

Dalam hal elemen ini kekuatan perusahaan adalah memiliki beberapa saluran komunikasi dengan konsumen baik secara langsung maupun secara online. Adapun penggunaan setiap saluran disesuaikan dengan kebutuhan masing masing. Kemudian kelemahan perusahaan adalah belum memaksimalkan penggunakaan saluran komunikasi yang ada dikarenakan keterbatasan personil dan tenaga ahli dalam bidang marketing. Selanjutnya peluang perusahaan ternyata masih sangat besar dalam mengembangkan saluran komunikasi ini, salah satunya dengan penambahan personel yang berkompeten untuk mengelola setiap saluran komunikasi yang dimiliki.

Ancaman yang timbul lebih kepada ancaman eksternal dimana pesaing selalu mengembangkan saluran komunikasi mereka dengan para konsumen sehingga hubungan yang terjalin semakin baik dan banyak konsumen yang datang kepada para pesaing.

\section{- Customer Relationships}

Dalam menjalin hubungan baik dengan para konsumen kekuatan yang dimiliki perusahaan adalah mengelola komunitas animasi dengan baik dimana dari komunitas tersebut sering mendapat orderan. Kelemahannya adalah tidak bisa maksimal dalam me-manage dan mendata setiap konsumen yang datang sehingga perlu adanya manajemen pengelolaan konsumen yang baik. Peluang perusahaan dalam elemen ini masih cukup luas dimana setiap konsumen membutuhkan service yang baik sehingga proyek dapat datang secara berkelanjutan. Selain itu juga perlu adanya sebuah cara yang jitu dalam mengelola konsumen sehingga perusahaan selalu mengetahui kebutuhan dari setiap konsumen. Ancamannya adalah dari konsumen itu sendiri, jika terlalu dalam menjalin hubungan didalam komunitas maka lambat laun akan mengetahui kekurangan perusahaan.

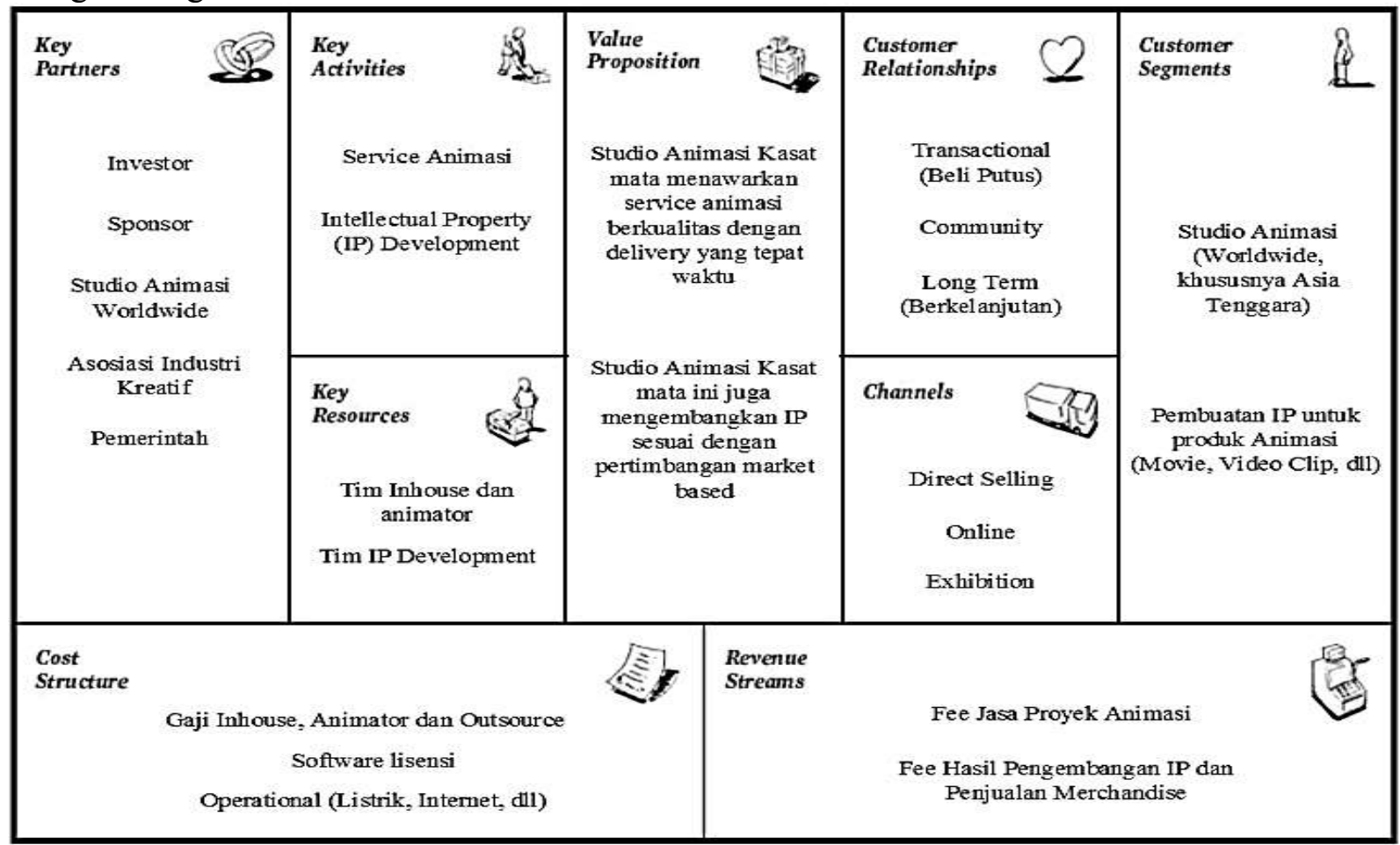

Gambar 3. Pemetaan Business Model Canvas Awal. 


\section{- Revenue Streams}

Kekuatan perusahaan yang terdapat pada elemen ini adalah dalam hal penetapan harga perusahaan ini bersifat dynamic pricing sehingga konsumen cukup tertarik dengan sistem tersebut. Kekurangannya adalah karena tidak adanya difersifikasi produk / jasa yang seimbang maka omset yang masuk hanya bertumpu pada proyek animasi. Sehingga jika proyek yang masuk sedang tidak stabil maka revenue yang didapatkan akan terganggu karena hanya bergantung pada satu arus pendapatan saja.

Peluang perusahaan pada elemen ini akan bertambah jika perusahaan menambah lini bisnis baru sehingga revenue yang datang akan berasal dari beberapa produk / jasa animasi yang berbeda. Ancamannya adalah jika ada pesaing yang menetapkan harga lebih kompetitif maka bisa jadi konsumen akan beralih ke perusahaan animasi lain.

\section{- Key Resources}

Kekuatan utama pada elemen ini terletak pada tim animator yang handal berpengalaman lebih dari 10 tahun menggarap proyek-proyek animasi besar di Indonesia. Adapun kelemahan perusahaan pada elemen bisnis ini adalah terletak pada infrastruktur dan sarana prasarana yang tidak up to date sehingga perlu dilakukan peremajaan infrastruktur seperti komputer berbasis animasi dengan teknologi keluaran terbaru dan software up date yang mumpuni. Adapun peluang yang bisa dimanfaatkan cukup besar jika peremajaan infrastruktur dilakukan maka dengan kombinasi kemampuan animasi yang dimiliki oleh setiap personil akan menambah lini produksi akan semakin solid.
Dengan perpaduan tersebut maka waktu pembuatan animasi maupun lini bisnis lain akan semakin efektif dan efisien. Ancaman internal yang dihadapi adalah faktor tenaga kerja yang bisa sewaktu - waktu mengundurkan diri sehingga membuat sumber daya yang dimiliki perusahaan berkurang dan harus mencari sumber daya baru sehingga dibutuhkan waktu untuk membentuk tim yang solid lagi. Ancaman dari luar yaitu kemajuan jaman yang selalu berkembang dengan cepat dari masa ke masa sehingga menyebabkan infrastruktur harus selalu di perbarui.

\section{- Key Activities}

Adapun kekuatan pada elemen ini adalah pada pengembangan IP yang selalu dilakukan perusahaan sehingga sejak berdirinya hingga saat ini perusahaan animasi ini memiliki beberapa karya animasi pribadi baik yang sudah di publikasikan maupun yang belum. Kelemahannya terletak pada sistem perusahaan yang belum terpadu sehingga aktifitas yang dilakukan terkadang berlebihan untuk suatu proyek tertentu. Peluang yang dimiliki perusahaan dalam elemen ini cukup banyak jika perusahaan membangun lini bisnis baru nantinya aktivitas yang dilakukan dapat saling mendukung antara satu lini bisnis dengan yang lainnya. Contoh seperti pengembangan IP, nantinya karya tersebut dapat digunakan sebagai karakter animasi maupun dibuat kedalam bentuk merchandise dan dijual. Adapun ancaman yang dihadapi adalah aktivitas perusahaan dapat terganggu jika adanya permasalahan internal yang terjadi seperti semangat kerja karyawan yang naik turun dan juga tingkat stress karyawan yang berbeda beda. 


\section{- Key Partnerships}

Kekuatan utama perusahaan pada elemen ini adalah terletak pada kerja sama dengan studio animasi lain dan juga perusahaan ditunjuk sebagai pengelola industri kreatif karena pengalaman yang dimiliki. Kelemahan pada elemen ini adalah kurangnya perusahaan dalam mengentertain para partner perusahaan sehingga beberapa rekan bisnis pergi begitu saja. Adapun peluangnya adalah banyak perusahaan animasi lain, ataupun pemerintah yang siap untuk diajak bekerja sama dalam membuat karya animasi. Ancaman yang timbul berupa rekan bisnis yang terkadang tidak bisa diajak bekerja sama dengan baik ataupun seketika pergi begitu saja.

\section{- $\quad$ Cost Structure}

Kekuatan utama pada elemen ini adalah perusahaan selalu melakukan efisiensi terhadap biaya tenaga kerja seperti adanya double job yang dibebankan kepada karyawan. Contohnya seorang animator sekaligus juga bisa menjadi bagian dari tim IP development. Kelemahan dari elemen ini didalam perusahaan kasat mata yaitu perusahaan jarang memperbarui sistem keuangannya sehingga masih menggunakan metode lama. Peluang yang ditawarkan cukup banyak seperti penggunaan teknologi baru dalam sistem bisnis nya yang berdampak pada pengurangan biaya karyawan. Ancamannya terletak pada sistem perekonomian baik regional maupun nasional yang selalu berubah seperti inflasi dan kenaikan upah minimum regional karena hal tersebut akan dapat merubah struktur biaya pada sistem bisnis ini.

\subsection{Pengembangan Business Model Canvas Baru}

Jika dilihat secara keseluruhan business model canvas yang terbentuk perusahaan animasi kasat mata ini akan memaksimalkan peluang diindustri animasi dengan memasuki beberapa bisnis lini bisnis baru. Salah satu bisnis baru yang nantinya akan menjadi fokus utama perusahaan adalah mendirikan sekolah animasi untuk mencetak para animator handal yang siap untuk bekerja baik didalam maupun luar negeri. Kemudian masih terkait dengan sekolah animasi, perusahaan juga akan masuk ke pasar anak usia dini yaitu workshop animasi untuk anak usia dini sampai anak usia menengah.

Tujuannya adalah untuk memperkenalkan dunia animasi kepada anak - anak dimana saat ini sudah banyak lembaga kursus yang menyediakan hal semacam itu. Selanjutnya perusahaan ini juga akan menyelenggarakan pelatihan animasi untuk masyarakat umum untuk lebih memperkenalkan animasi secara luas dengan metode yang mudah dipahami. Sehingga ketiga segmen bisnis ini nantinya akan berjalan secara beriringan dan terpadu.

Selain itu perusahaan juga akan mengembangkan Intellectual Property (IP) untuk kebutuhan sendiri dimana nantinya akan terintegrasi dengan bisnis pendukung lain yaitu pembuatan merchandise. Merchandise ini akan diproduksi secara berkala dengan bantuan partner bisnis di bidang produksi merchandise dan penjualannya akan masuk ke skala besar menggunakan media online maupun offline. Segmen bisnis yang terakhir adalah pembuatan animasi dimana segmen bisnis ini akan tetap dipertahankan sebagai jati diri perusahaan yang awalnya bermula dari pembuatan film animasi dengan fokus pada pembuatan karakter animasi. Nantinya juga pembuatan film animasi ini juga akan terintegrasi dengan pengembangan IP dikarenakan karakter IP yang sudah jadi nantinya dapat digunakan untuk proyek animasi.

Adapun setiap elemen dalam business model canvas mengalami penambahan baik penambahan yang berupa aktifitas maupun aspek pendukung dari fasilitas tersebut. Gambar berikut menjelaskan mengenai pemetaan business model canvas (BMC) baru yang terbentuk pasca analisis.

Selanjutnya akan dijelaskan mengenai business model canvas baru yang terbentuk berdasarkan hasil dari analisis yang telah dilakukan. Adapun penambahan pada setiap 
elemen business model canvas dan modifikasi terhadap analisis biaya adalah sebagai berikut :

\section{- Customer Segments}

Pada elemen ini perusahaan kasat mata memiliki tambahan customer segments yaitu lembaga pendidikan dan pemerintah sebagai konsumen untuk pelatihan animasi. Segmentasi konsumen selanjutnya adalah perusahaan merchandise dimana nantinya perusahaan merchandise menjadi konsumen dalam pembuatan merchandise berlatar belakang animasi yang diproduksi dan dijual dengan dengan jumlah banyak atau dengan kata lain dikapitalisasi. Selanjutnya adalah segmen pasar anak muda yang baru saja lulus SMA atau lulus kuliah yang mempunyai minat di bidang animasi, dimana pasar ini nantinya akan menjadi konsumen terbesar perusahaan kasat mata pada lini bisnis sekolah animasi bersertifikat. Segmentasi konsumen hasil pengembangan selanjutnya adalah balita dan anak usia dini sebagai konsumen dalam lini bisnis workshop animasi untuk anak dimana tujuannya adalah untuk memperkenalkan animasi sejak dini sehingga dapat melatih imajinasi dan kreatifitas anak.

\section{- Value Proposition}

Pada elemen ini value proposition yang sudah dimiliki oleh perusahaan tetap dipertahankan dan ditingkatkan. Kemudian terdapat value proposition baru yang ditawarkan kepada konsumen hasil dari pengembangan bisnis menggunakan analisis SWOT. Pertama adalah pada lini bisnis sekolah animasi dimana kurikulum yang digunakan berbasis internasional yang sering digunakan oleh sekolah animasi kelas dunia seperti dijepang dan amerika sehingga nantinya lulusan sekolah ini mendapatkan sertifikasi internasional yang diakui.
Selanjutnya pada lini bisnis workshop anak dimana value proposition yang ditawarkan adalah penggunaan media sederhana yang mudah dipahami oleh anak serta menggunakan sistem pengajaran yang dinamis. Kemudian dikarenakan perusahaan animasi ini memiliki beberapa lini bisnis yang terintegrasi sehingga membuat harga jual produk dan jasa yang ditawarkan pun menjadi semakin ekonomis.

\section{- Channels}

Saluran komunikasi dan distribusi yang dimiliki perusahaan animasi ini sudah cukup lengkap yaitu melalui direct selling, online dan exhibition. Dimana beberapa saluran tersebut sudah cukup efektif untuk menjangkau kebutuhan konsumen. Namun dengan adanya analisis yang dilakukan maka muncul saluran informasi baru yang dapat digunakan untuk berinteraksi dengan konsumen yaitu melalui tangan ketiga (third parties), maksudnya disini adalah melalui agen agen perusahaan animasi di setiap lembaga pendidikan yang menjalin kerja sama dengan perusahaan animasi kasat mata. Nantinya diharapkan saluran komunikasi yang sudah ada dapat dimanfaatkan secara maksimal dan terus dikembangkan.

\section{- Customer Relationships}

Setelah dilakukan analisis terhadap model bisnis perusahaan maka munculah hubungan baru yang terjalin antara perusahaan dengan konsumen yaitu adalah hubungan secara kolaborasi dalam mengerjakan sebuah karya animasi maupun dalam lini bisnis pendukung. Sebelumnya memang telah terbentuk budaya kolaborasi antara perusahaan ini dengan perusahaan animasi lain namun hubungan yang terjalin tidak bersinergi dengan baik sehingga terkadang menyebabkan perusahaan ini merugi. 
Hal tersebut dikarenakan tidak adanya sistem yang menaungi hubungan kolaborasi ini. Selanjutnya perusahaan kasat mata akan lebih serius dalam membangun budaya kolaborasi ini dengan perusahaan lain dengan tujuan memberikan keuntungan bagi kedua belah pihak. Diharapkan budaya kolaborasi ini dapat saling terintegrasi dalam merekatkan hubungan dengan konsumen perusahaan.

\section{- Revenue Streams}

Berdasarkan analisis yang telah dilakukan terhadap model bisnis perusahaan maka peneliti mengusulkan pengembangan bisnis dengan mengadakan lini bisnis baru sebagai fokus perusahaan dalam mendapatkan keuntungan. Adapun arus pendapatan tambahan disamping fee jasa proyek animasi serta fee pengembangan IP dan penjualan merchandise adalah fee yang didapatkan dari jasa sekolah animasi yang ditawarkan dimana nantinya arus pendapatan ini merupakan yang terbesar serta menjadi fokus utama perusahaan. Arus pendapatan selanjutnya adalah fee jasa workshop anak dan pelatihan animasi untuk umum. Nantinya keseluruhan lini bisnis akan berjalan secara terintegrasi. Keseluruhan arus pendapatan ini juga telah dianalisis untuk mengetahui seberapa menguntungkankah investasi dibidang animasi ini.

\section{- Key Resources}

Hasil analisis SWOT mengatakan bahwa selain sumber daya utama perusahaan yang sudah ada yaitu tim inhouse, animator serta tim IP development, perusahaan membutuhkan sumber daya utama lainnya untuk mendukung berbagai lini bisnis yang akan dijalankan yaitu pembangunan infrastruktur yang memadai.
Adapun infrastruktur yang ada sekarang sudah tidak up to date serta kurang compatible dengan lini bisnis baru yang akan dijalankan sehingga infrastruktur yang memadai merupakan sumber daya yang sangat penting untuk diadakan. Nominal biaya yang dibutuhkan pun tidak sedikit sehingga membutuhkan dukungan investasi baru dalam menjalankan model bisnis baru ini.

\section{- Key Activities}

Aktifitas utama perusahaan bertambah dengan adanya penambahan lini bisnis yang diusulkan dari analisis sebelumnya. Adapun penambahannya yaitu aktifitas sekolah animasi regular yang akan sangat menyibukan perusahaan dimana sekolah animasi akan dilaksanakan setiap hari kecuali hari libur. Aktifitas selanjutnya adalah workshop animasi dan pelatihan animasi, kegiatan ini akan berjalan secara beriringan karena latar belakang aktifitasnya sama namun obyeknya berbeda. Kegiatan ini akan dilaksanakan beberapa kali dalam 1 bulan tergantung dari jadwal yang dibuat berdasarkan kondisi pasar. Aktifitas utama selanjutnya adalah produksi merchandise dimana aktifitas ini dilakukan bersama dengan perusahaan yang menjadi partner sehingga aktifitas yang dilakukan di kasat mata lebih sebatas designing dan penjualan. Keseluruhan aktifitas ini nantinya akan dilakukan secara terpadu dan terintegrasi sehingga dimungkinkan satu karyawan melakukan beberapa pekerjaan di lini bisnis berbeda. Perusahaan ini nantinya akan menganut prinsip lean production dalam bisnisnya. 


\section{- Key Partnerships}

Elemen selanjutnya yang mengalami pengembangan pasca analisis adalah key partnership dimana pada elemen ini perusahaan menambahkan partner utama dalam menjalankan rancangan bisnis model yang baru nantinya. Partner yang pertama adalah software developer dimana hal ini dilakukan untuk dapat menekan biaya sewa software yang merupakan mesin utama pada produksi animasi. Selain itu pendekatan ini juga bertujuan untuk mempermudah pengadaan sertifikasi software untuk para murid di sekolah animasi. Partner baru yang kedua adalah perusahaan produksi merchandise dimana hal ini dilakukan agar saling menguntungkan kedua belah pihak dalam produksi merchandise dibidang animasi.

Partner selanjutnya adalah lembaga pendidikan dimana kerja sama ini bertujuan untuk mengenalkan animasi lebih dalam kepada siswa siswa umum, selain itu juga dapat menarik minat para siswa tersebut untuk belajar animasi lebih dalam disekolah animasi yang di selenggarakan oleh perusahaan kasat mata. Partner yang selanjutnya adalah komunitas lintas media dimana kerja sama ini dilakukan untuk mencari pasar workshop anak dan pelatihan animasi.

\section{- Cost Structure}

Pada elemen ini selain biaya yang sudah dijelaskan pada business model canvas awal disini terdapat tambahan biaya yang harus dikeluarkan untuk dapat menjalankan model bisnis yang telah dirancang. Adapun tambahannya adalah biaya pemasaran dimana peneliti merasa biaya untuk kegiatan ini cukup penting untuk dianggarkan karena nantinya perusahaan ini bertujuan untuk menaikan namanya kembali kepasaran dengan versi yang berbeda dari sebelumnya. Komponen biaya selanjutnya adalah biaya untuk pengemangan dan perawatan infrastruktur dan fasilitas dimana hal ini perlu dilakukan demi menggapai tujuan perusahaan dan selalu memberikan performa terbaik kepada para konsumen.

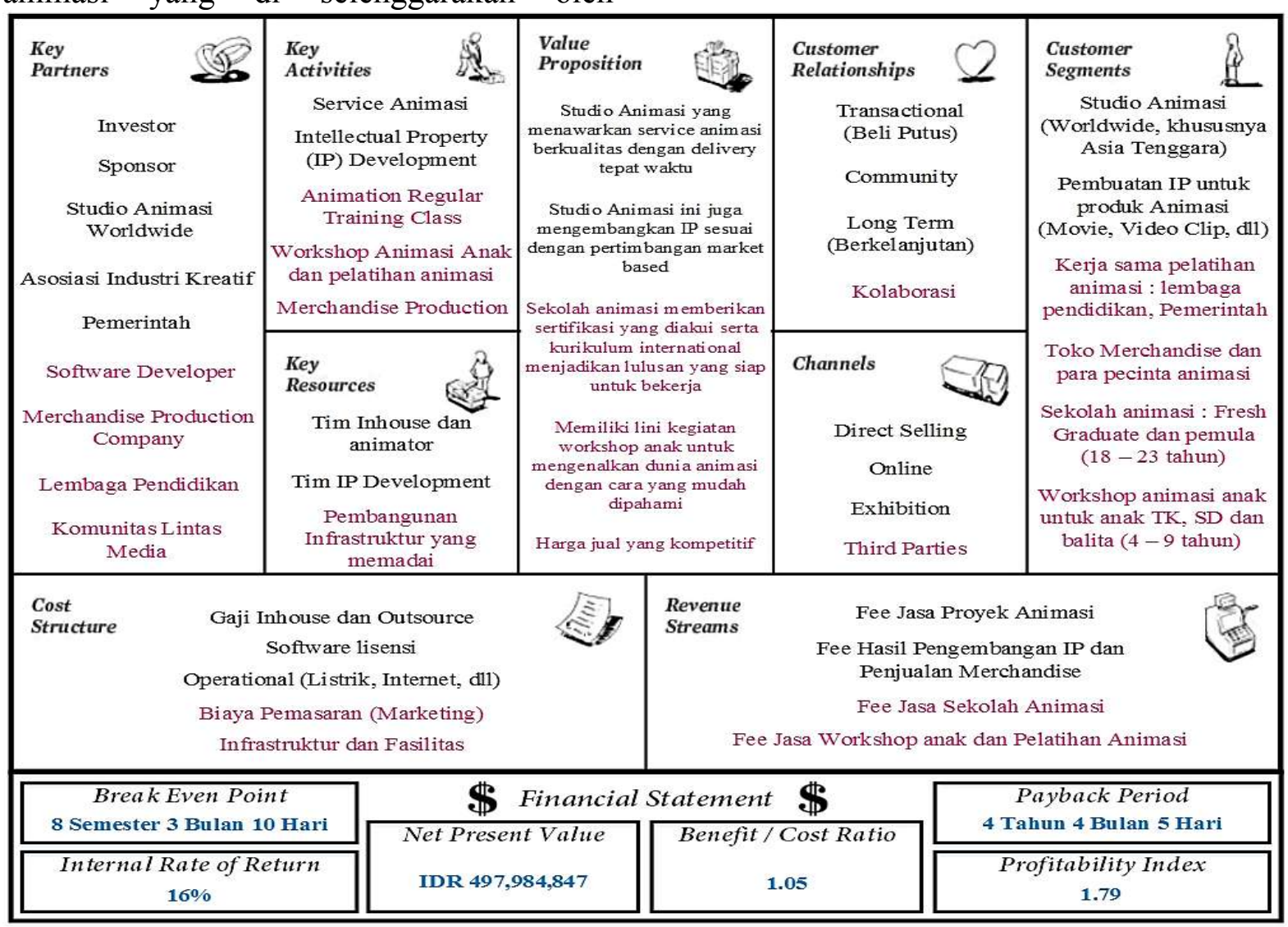

Gambar 4. Pemetaan Business Model Canvas Baru. 
Pada penenlitian ini Business Canvas Model (BMC) yang digunakan cukup berbeda dari biasanya karena menggunakan BMC yang telah dikembangkan dengan memodifikasi elemen yang ada. Dimana pada BMC ini ditambahkan elemen kesepuluh yaitu financial statement dimana didalamnya memuat analisis biaya terhadap keseluruhan business model canvas baru yang terbentuk.

Sehingga bisnis model ini merupakan business model canvas yang terbatasi oleh biaya dikarenakan analisisnya mempertimbangkan elemen kelayakan investasi dengan perhitungan analisis biaya yang biasanya digunakan dalam uji kelayakan investasi. Adapun analisis biaya yang digunakan adalah net present value (NPV), benefit / cost ratio (BCR), profitability index (PI), internal rate of return (IRR), payback period (PP) dan break even point (BEP).

Pada analisis biaya ini masa ekonomis proyek yang digunakan adalah selama 6 tahun dimana penentuan ini telah mempertimbangkan berbagai faktor baik faktor ekonomi, social, latar belakang bisnis maupun faktor pertumbuhan bisnis di Indonesia. Adapun pembahasan lebih lanjut mengenai hasil dari perhitungan analisis biaya adalah sebagai berikut :

\section{a. Net Present Value (NPV)}

Alat analisis yang pertama adalah net present value (NPV) yang pada penelitian ini menghasilkan nilai positif yaitu sebesar Rp. 497,984,847 dengan menggunakan discount factor sebesar $12 \%$ dimana discount factor ini ditentutan berdasarkan data rata - rata per tahun tingkat suku bunga kredit (cost of capital) di Bank Indonesia (Bank Indonesia, 2017).
Kemudian adapun NPV yang dihasilkan dengan mempertimbangkan nilai sisa aset [20] perusahaan pada saat tahun keenam juga otomatis menghasilkan nilai positif yaitu sebesar Rp. 5,124,106,378 dengan menggunakan discount factor yang sama. Berdasarkan nilai NPV diatas maka proyek investasi ini dinyatakan layak karena nilai NPV berada diatas 0 (nol).

\section{b. Benefit / Cost Ratio (BCR)}

Pada alat analisis ini data yang digunakan secara keseluruhan hampir sama dengan alat analisis net present value. Adapun alat analisis ini merupakan perbandingan antara total keuntungan (benefit) dengan total pengeluran (cost) yang sudah mempertimbangkan nilai waktu dari uang (value time of money). Hasil dari analisis ini berada pada rasio 1.05. Dengan rasio yang berada diatas 1 maka berdasarkan alat analisis ini proyek investasi yang akan dijalankan dinyatakan layak.

\section{c. Profitability Index (PI)}

Alat analisis selanjutnya adalah perhitungan profitability index (PI) yaitu merupakan perhitungan index perbandingan antara total net cash flow (arus pemasukan bersih) selama umur ekonomis proyek yang sudah mempertimbangkan time value of money dengan total biaya investasi awal. Adapun hasil yang didapatkan pada perhitungan ini adalah senilai 1.109. Dengan hasil ini menunjukan index dari proyek investasi ini menguntungkan karena angka yang didapatkan lebih besar dari pada 1 , dengan demikian berdasarkan alat analisis ini proyek investasi dinyatakan layak. 


\section{d. Internal Rate of Return (IRR)}

Pada perhitungan ini alat analisis yang digunakan adalah untuk menghitung persentase (rate) seberapa besar nilai investasi tersebut akan menghasilkan keuntungan bersih. Adapun hasil yang didapatkan pada perhitungan internal rate of return (IRR) terhadap proyek investasi ini adalah sebesar $16 \%$. Dengan hasil tersebut maka menurut standar analisis IRR proyek ini layak karena nilai IRR nya diatas dari nilai opportunity cost of capital yang sebesar $12 \%$. Dalam arti lain bahwa proyek ini menghasilkan laba bersih lebih besar dari tingkat suku bunga kredit di bank.

\section{e. Payback Period (PP)}

Perhitungan payback period merupakan suatu alat analisis yang digunakan untuk mengetahui kapan nilai investasi yang dikeluarkan akan kembali. Pada penelitian ini dilakukan 2 kali analisis payback period, yang pertama adalah penentuan payback period (PP) tanpa mempertimbangkan nilai waktu dari uang (time value of money) sedangkan yang kedua adalah penentuan payback period dengan mempertingkangkan time value of money yaitu menggunakan discount factor (i) sebesar 5\% yang ditentukan dari rata - rata batas atas inflasi di Indonesia 1 tahun belakangan (Bank Indonesia).

Adapun hasil analisis pertama diperoleh payback period yaitu 4 tahun 4 bulan 5 hari sedangkan pada analisis kedua diperoleh hasil discounted payback period yaitu 4 tahun 9 bulan 10 hari. Dapat dilihat bahwa analisis kedua menunjukan waktu lebih lama daripada analisis pertama, hal tersebut dikarenakan analisis kedua menggunakan perhitungan present value atau dapat dikatakan mempertimbangkan time value of money.
Walaupun demikian kedua analisis tersebut dianggap layak karena menunjukan waktu payback period lebih cepat daripada umur ekonomis proyek yaitu 6 tahun. Dengan demikian dari hasil analisis payback period proyek investasi yang dirancang ini layak untuk dijalankan.

\section{f. Break Event Point (BEP)}

Analisis ini merupakan alat analisis terakhir dari analisis biaya dimana tujuan dari alat analisis ini hamper sama dengan alat analisis payback period yaitu menentukan titik impas dari biaya investasi yang dikeluarkan. Untuk sedikit membedakan maka alat analisis ini menggunakan time frame semester. Adapun konsep yang digunakan pada analisis ini adalah dengan cara membandingkan total pemasukan (cash in) dengan total pengeluaran (cash out) yang diterjemahkan dalam bentuk grafik, sehingga didapatkan titik perpotongan antara kedua grafik biaya tersebut pada waktu tertentu.

Adapun hasil dari analisis ini adalah titik BEP terletak antara semester kedelapan dan semester kesembilan. Tepatnya terletak di 8 semester 3 bulan 10 hari. Dengan demikian menurut alat analisis ini proyek investasi dinyatakan layak karena BEP terjadi sebelum umur ekonomis proyek berakhir yaitu 12 semester.

\section{KESIMPULAN}

Berdasarkan hasil penelitian yang telah dilakukan maka dapat disimpulkan beberapa hal sebagai berikut :

1. Pengembangan business model canvas yang terbatasi oleh biaya pada perusahaan animasi kasat mata dengan pendekatan analisis SWOT dapat dikatakan layak untuk dijalankan. Hasil tersebut mengacu pada keseluruhan komponen analisis biaya yang membatasi setiap elemen pada business model canvas baru yang terbentuk. 
Dimana keseluruhan komponen analisis biaya tersebut menyatakan rancangan model bisnis ini layak untuk dijalankan. Modifikasi pada business model canvas dilakukan untuk memperoleh bisnis model yang optimal. Adapun lini bisnis baru hasil pengembangan pada penelitian ini ada 5 yaitu sekolah animasi yang menjadi fokus utama perusahaan, pelatihan animasi untuk umum dan workshop animasi untuk anak, pengembangan IP disertai produksi merchandise dan proyek pembuatan animasi. Kelima lini bisnis tersebut dapat dijalankan secara terintegrasi dengan acuan business model canvas yang telah dimodifikasi pada penelitian ini.

2. Hasil penelitian ini berupa penjelasan model bisnis yang terstruktur dalam bentuk Business Model Canvas (BMC) serta analisis biaya dengan beberapa alat ukur berbeda. Dimana hasil tersebut dapat digunakan sebagai acuan baik oleh perusahaan dalam menjalankan bisnisnya maupun oleh para investor dalam melihat seberapa menguntungkannya investasi dalam bidang animasi ini. Adapun prospek kedepan terhadap bisnis ini masih cukup besar untuk dikembangkan karena berdasarkan analisis SWOT yang dilakukan menunjukan bahwa bisnis ini masih memiliki banyak peluang yang dapat dimanfaatkan dengan baik.

\section{DAFTAR PUSTAKA}

Bank Indonesia., 2017. Laporan Perhitungan Inflasi Tahunan, 2016-2017. Retrieved from www.bi.go.id: http://www.bi.go.id/id/moneter/infl asi/data/.

Bank Indonesia., 2017. Tingkat suku bunga dasar kredit, 2016. Retrieved from www.bi.go.id:

http://www.bi.go.id/id/perbankan/s uku-bunga-dasar/.

Bateman, T.S., Snell, S.A., 2009. Management. New York: McGraw Hill.

Chandra, D., 2016. Model bisnis pada perusahaan $\mathrm{X}$ menggunakan business model canvas. Agora, 4(1), 18-25.

Clark, T., Osterwalder, A., \& Pigneur, Y., 2012. Business model you: A onepage method for reinventing your career. John Wiley \& Sons.

Fathurahman, A., \& Mauluddin, Y., 2016. Analisis model bisnis pada pengembangan usaha outbond di villa buleud. Jurnal Kalibrasi, 14(1).

Geertz, C., 1994. Thick description: Toward an interpretive theory of culture. Readings in the philosophy of social science, 213-231. 
Hidayat, F., 2016, Februari. REI: Kenaikan Harga Rumah di DIY Rata-Rata 10-15 Persen pada Tahun 2016. Retrieved from www.beritasatu.com: http://www.beritasatu.com/hunian/ 349095-rei-kenaikan-hargarumah-ratarata-1015-persen.

Maskur., 2014. Analisis kelayakan investasi SPBU CV. insani subur sejahtera di marangkayu kabupaten kutai kartanegara. e-Journal Administrasi Bisnis, 2 (4), 2014: 527 - 540 ISSN 2355-5408.

Osterwalder, A., \& Pigneur, Y., 2010. Business model generation: a handbook for visionaries, game changers, and challengers. John Wiley \& Sons.

Rangkuti, F., 2006. SWOT Analysis Techniques Dissecting the Business Case. PT Gramedia Pustaka Utama.

Surjogondokusumo, B. N., 2016. Analisis model bisnis pada restoran yung ho dengan menggunakan bussines model canvas. Agora, 4(2), 229237.

Tim PPM Manajemen., 2012. Business Model Canvas. Jakarta: Penerbit PPM.

Umar, Husein., 2003. Studi kelayakan bisnis : Teknik menganalisis kelayakan rencana bisnis secara komperehensip. Gramedia Pustaka Utama, Ed ke-2. Jakarta.

Utomo, S, S, Dkk., 2014. Analisis kelayakan finansial dan lingkungan industri terhadap pembangunan sarana retest, repair dan repaint tabung gas LPG 3Kg (Studi kasus PT. MK tabanan, bali). Jurnal Ekonomi Akuntansi dan Manajemen, S1, Vol.13 No.1, ISSN 2459 - 9816. 